\title{
DŁUŻNIK ZAJĘTEJ WIERZYTELNOŚCI W POSTĘPOWANIU EGZEKUCYJNYM W ADMINISTRACJI
}

\section{UWAGI WPROWADZAJĄCE}

Sytuacja prawnoprocesowa dłużnika zajętej wierzytelności jest wyrazem złożoności problematyki przymusowego wykonania obowiązków pieniężnych w trybie egzekucji administracyjnej, zwłaszcza zaś problemów, jakie powstaja przy okazji zetknięcia prawa procesowego administracyjnego z instytucjami prawa prywatnego. Z jednej strony bowiem dłużnik zajętej wierzytelności jest podmiotem prawa prywatnego i podlega regułom rządzącym w tym obszarze, z drugiej zaś - jest on podmiotem obowiązków procesowych nakładanych na niego w drodze władczej; przede wszystkim jest zobowiązany do realizowania zajętych wierzytelności na rzecz administracyjnego organu egzekucyjnego.

Przedmiotem podjętych rozważań będzie analiza rozwiązań prawnych przyjętych przez ustawodawcę w ustawie z 17 czerwca 1966 r. o postępowaniu egzekucyjnym $\mathrm{w}$ administracji ${ }^{1}-\mathrm{w}$ odniesieniu do przymusowej realizacji praw majątkowych przez dłużnika zajętej wierzytelności, w celu ukazania głównych cech sytuacji procesowej tego podmiotu we wskazanym postępowaniu.

\section{STATUS PRAWNOPROCESOWY DLUŻNIKA ZAJĘTEJ WIERZYTELNOŚCI}

Dłużnik zajętej wierzytelności, nazywany też - na wzór terminu funkcjonującego w literaturze w odniesieniu do tożsamego podmiotu w sądowym postępowaniu egzekucyjnym - mianem „poddłużnika” lub „trzeciodłużnika”, a także „quasi-egzekutora” 3 - jest podmiotem, od którego podmiot wskazany w tytule wykonawczym jako zobowiązany może żądać spełnienia świadczenia na jego

1 T.jedn.: Dz. U. 2012, poz. 1015 ze zm. (dalej: upea).

${ }^{2}$ Por. F. Zedler, Postępowanie zabezpieczajace i egzekucyjne. Komentarz, t. 3, Toruń 1995, s. 97; M. Walasik, Odpowiedzialność odszkodowawcza dtużnika wierzytelności zajętej w postępowaniu cywilnym, „Przegląd Sądowy” 2004, nr 7-8, s. 65.

${ }^{3}$ R. Hauser, Z. Leoński, w: R. Hauser, A. Skoczylas (red.), Postępowanie egzekucyjne $w$ administracji. Komentarz, Warszawa 2012, s. 24; A. Skoczylas, Postepowanie egzekucyjne w administracji, w: R. Hauser, Z. Niewiadomski, A. Wróbel (red.), System prawa administracyjnego, t. 9: Prawo procesowe administracyjne, Warszawa 2010, s. 368 i powołana tam literatura. 
rzecz ${ }^{4}$. Według definicji legalnej, zawartej w art. 1a pkt 3 upea, dłużnikiem zajętej wierzytelności jest dłużnik zobowiązanego, jak również bank, pracodawca, podmiot prowadzący działalność maklerska, trasat oraz inne podmioty realizujące, na wezwanie organu egzekucyjnego, zajęcie wierzytelności lub innego prawa majątkowego zobowiązanego. W doktrynie wskazuje się, że niepełnego charakteru tej definicji należy upatrywać w tym, że nie zostały w niej wymienione enumeratywnie wszystkie podmioty będące w rozumieniu ustawy dłużnikami zajętej wierzytelności. Określenie to jest bowiem zbiorczą nazwa wielu podmiotów biorących udział w egzekucji administracyjnej należności pieniężnych, realizujacych na wezwanie organu egzekucyjnego zajęcie wierzytelności oraz innych praw majątkowych ${ }^{5}$. Podmiotem tym może być m.in. zleceniobiorca robót i usług, organ właściwy do wydania polecenia wypłaty wierzytelności należnej zobowiązanemu od jednostki budżetowej, zakładu budżetowego lub funduszy pozostajacych w ich zarządzie, podmiot, który udzielił zabezpieczenia na zajętej wierzytelności (np. dłużnik hipoteczny) ${ }^{6}$, czy podmiot zobowiązany z tytułu pożyczki. Istota omawianej instytucji dotyczy realizacji zajęcia wierzytelności albo innego prawa majątkowego, które wynika bądź ze stosunku pracy, bądź z umowy rachunku bankowego albo tė̇ z innych stosunków prawnych.

Dłużnik zajętej wierzytelności występuje w dwóch różnych stosunkach prawnych: z organem egzekucyjnym łaczy go stosunek administracyjnoprawny, natomiast ze zobowiązanym - stosunek cywilnoprawny ${ }^{7}$. Zajęcie wierzytelności nie powoduje zniesienia stosunku cywilnoprawnego łączącego zobowiązanego i dłużnika zajętej wierzytelności. Owe zniesienie tego stosunku może nastapić dopiero na skutek realizacji zajęcia wierzytelności lub prawa majątkowego, kiedy to następuje zmiana dotychczasowej treści stosunku obligacyjnego łączącego dłużnika zajętej wierzytelności i zobowiązanego, będącego w tym stosunku wierzycielem ${ }^{8}$. Drugim skutkiem zajęcia wierzytelności jest nawiązanie między organem egzekucyjnym i dłużnikiem zajętej wierzytelności administracyjnoprawnego stosunku procesowego, w ramach którego organ egzekucyjny dokonuje wobec dłużnika zajętej wierzytelności czynności o charakterze władczym ${ }^{9}$. Innymi słowy, od momentu zajęcia poddłużnik zyskuje

${ }^{4}$ E. Cisowska-Sakrajda, w: J. P. Tarno (red.), Doradca podatkowy w egzekucji administracyjnej należności pieniężnych, Warszawa 2012, s. 167.

${ }^{5}$ R. Hauser, Z. Leoński, w: R. Hauser, A. Skoczylas (red.), op. cit., s. 23.

${ }^{6}$ E. Cisowska-Sakrajda, w: J. P. Tarno (red.), op. cit., s. 167.

7 M. Masternak, Dtużnik zajętej wierzytelności w egzekucji administracyjnej, w: J. Niczyporuk, S. Fundowicz, J. Radwanowicz (red.), System egzekucji administracyjnej, Warszawa 2004, s. 191; R. Hauser, Z. Leoński, w: R. Hauser, A. Skoczylas (red.), op. cit., s. 24.

8 M. Masternak, op. cit., s. 182.

${ }^{9} \mathrm{Na}$ władczy charakter wezwania wystosowanego do poddłużnika zwracał uwagę SN m.in. w wyroku z 19 lutego 1982 r., II CR 8/82, OSPiKA 1982, nr 11, poz. 189. Jednakże w sądowym postępowaniu egzekucyjnym w wyniku zajęcia wierzytelności powstaje odmienna sytuacja określana mianem „podstawienia wierzyciela w prawa dłużnika zobowiązanego” - zob. M. Walasik, op. cit., s. 78 i przywołana tam literatura. Przy czym wskazuje się, że w tym wypadku zachodzi podstawienie procesowe względne-zob. W. Siedlecki, w: Z. Resich, W. Siedlecki (red.), Kodeks postępowania cywilnego. Komentarz. Część druga. Postępowanie zabezpieczajace i egzekucyjne, Warszawa 1976, s. 1233; S. Cieślak, w: J. Jankowski (red.), Kodeks postepowania cywilnego. Postepowanie egzekucyjne. Komentarz do art. 758-1088, Warszawa 2011, s. 714-715. 
status podmiotu postępowania egzekucyjnego, dotąd bowiem był osoba trzecia ${ }^{10}$. W moim przekonaniu istnienie pomiędzy organem egzekucyjnym i poddłużnikiem stosunku o charakterze administracyjnoprawnym wyklucza możliwość przyjęcia poglądu, by w wyniku zajęcia wierzytelności organ egzekucyjny wstępował w miejsce zobowiązanego i mógł wykonywać wobec dłużnika zajętej wierzytelności uprawnienia przysługujące zobowiązanemu ${ }^{11}$. Sytuację procesową poddłużnika, w tym przysługujace mu uprawnienia i ciążące na nim obowiązki, konstytuują przepisy ustawy egzekucyjnej. W sposób odrębny został też uregulowany sposób procedowania organu egzekucyjnego $\mathrm{w}$ sytuacji niewykonywania przez trzeciodłużnika obowiązku wynikającego z zajęcia wierzytelności.

Ze stosunku procesowego pomiędzy organem egzekucyjnym a dłużnikiem zajętej wierzytelności wypływa szereg obowiązków poddłużnika, wśród których charakter podstawowy posiada obowiązek zaniechania wypłaty zajętej wierzytelności (realizacji innego prawa majątkowego) do rąk zobowiązanego oraz przekazanie kwoty z tytułu tej wierzytelności (innego prawa majątkowego) organowi egzekucyjnemu aż do pełnego pokrycia egzekwowanych należności pieniężnych. Ponadto na dłużniku ciążą szczegółowe - wyartykułowane w ustawie obowiązki, które różnią się w zależności od rodzajów środków egzekucyjnych. Należy zwrócić uwagę, że - jak zasadnie wskazuje się w doktrynie - rola dłużnika zajętej wierzytelności w postępowaniu egzekucyjnym nie wiąże się co do zasady z podejmowaniem działań odbiegajaccych od działań, które ten podmiot podejmowałby w przypadku braku zajęcia wierzytelności. Podstawową konsekwencją zajęcia wierzytelności jest bowiem to, że świadczenie zostanie spełnione do rąk organu egzekucyjnego, a nie zobowiąanego ${ }^{12}$. Przy tym dłużnik zajętej wierzytelności jest obowiązany do naliczenia odsetek z tytułu niezapłacenia należności w terminie, należnych od następnego dnia po dniu wystawienia przez organ egzekucyjny zawiadomienia o zajęciu wierzytelności lub prawa majątkowego do dnia przekazania organowi egzekucyjnemu środków pieniężnych uzyskanych z zajęcia (art. $70 § 1$ upea). Niezależnie od tego, jeżeli poddłużnikowi jest wiadome, że zajęta wierzytelność lub inne prawo majątkowe zostały obciążone zastawem rejestrowym, wstrzymuje on realizację zajęcia i powiadamia o tym niezwłocznie organ egzekucyjny. Jeśli zaś należności pieniężnej dochodzonej przez organ egzekucyjny przysługuje

${ }_{10}$ Zob. B. Adamiak, w: eadem, J. Borkowski, Postepowanie administracyjne $i$ sqdowoadministracyjne, Warszawa 2012, s. 529-560, która wskazuje, że dłużnik zajętej wierzytelności uczestniczy w prowadzeniu postępowania egzekucyjnego. Por. też: L. Walentynowicz, Powództwo wierzyciela przeciwko dtużnikowi zajętej wierzytelności, w: P. Grzegorczyk, K. Knoppek, M. Walasik (red.), Proces cywilny. Nauka-Kodyfikacja-Praktyka. Księga jubileuszowa dedykowana Profesorowi Feliksowi Zedlerowi, Warszawa 2012, s. 813; P. Grzegorczyk, Powództwo o zwolnienie spod egzekucji administracyjnej, w: A. Skoczylas, J. Stankowski (red.), Aktualne problemy postepowania egzekucyjnego $w$ administracji, Wrocław 2013, s. 148-149.

11 Por. wyrok WSA w Gliwicach z 12 maja 2011 r., I SA/Gl 150/11, Legalis; P. Przybysz, Administracyjne środki prawne $w$ postepowaniu egzekucyjnym $w$ administracji, Warszawa 2012 , s. 195 - który twierdzi, że ewentualny spór między organem egzekucyjnym a dłużnikiem zajętej wierzytelności jest rozstrzygany w tym trybie i na takich zasadach, jakie wynikają z charakteru stosunku prawnego, w ramach którego powstała wierzytelność.

12 P. Przybysz, op. cit., s. 194. 
wcześniejsza kolejność zaspokojenia niż wierzytelności zabezpieczonej zastawem rejestrowym, organ egzekucyjny powiadamia o tym dłużnika zajętej wierzytelności, który niezwłocznie podejmuje wstrzymana realizację zajęcia (art. 70b upea).

\section{POSTĘPOWANIE WZGLĘDEM DLUŻNIKA ZAJĘTEJ WIERZYTELNOŚCI}

Stanowisko dłużnika zajętej wierzytelności wobec nałożonych na niego obowiązów posiada wpływ na dalszy przebieg postępowania egzekucyjnego. W tym względzie można rozróżnić dwa zasadnicze typy zachowań poddłużnika, z którymi wiążą się odmienne konsekwencje prawne w dalszym toku postępowania. Odmienna sytuacja ma miejsce, gdy dłużnik zajętej wierzytelności uznaje roszczenie (zajętą wierzytelność) ${ }^{13}$ i przekazuje środki organowi egzekucyjnemu, odmienna zaś gdy dłużnik co prawda uznaje roszczenie, jednak uchyla się od przekazania zajętej wierzytelności (art. 91 upea) albo nie uznaje roszczenia i nie realizuje bądź odmawia realizacji zajętej wierzytelności. W pierwszej z wymienionych sytuacji postępowanie egzekucyjne toczy się dalej w oparciu o dotychczasową podstawę. W drugim przypadku-zarówno gdy poddłużnik uznał roszczenie, jak i tego nie uczynił, a nie przekazuje środków na poczet egzekwowanego obowiązku - organ może przeprowadzić kontrolę prawidłowości realizacji zastosowanego środka egzekucyjnego (art. 71a $§ 1$ upea) ${ }^{14}$. Kompetencję do przeprowadzania kontroli ustawodawca przekazuje przede wszystkim naczelnikom urzędów skarbowych, właściwym organom miast na prawach powiatów oraz dyrektorom izby celnych (art. 71a $\S 2$ upea). Wbrew poglądom wyrażanym $\mathrm{w}$ doktrynie uważam, że kontrola u poddłużnika nie jest prowadzona odrębnie od postępowania egzekucyjnego prowadzonego wobec głównego zobowiązanego, lecz w ramach tego postępowania. Przy tym zgadzam się ze stanowiskiem, że odpowiednie zastosowanie w kwestiach nieuregulowanych, w tym odnośnie do reguł gromadzenia dowodów uchylania się przez dłużnika zajętej wierzytelności od ustawowych obowiązków dotyczących zajętej wierzytelności, znajdą przepisy Kodeksu postępowania admini-

${ }^{13}$ Należy przy tym zaznaczyć, że uznanie roszczenia przez poddłużnika nie wymaga żadnej szczególnej formy, może zostać dokonane w sposób dorozumiany, przykładowo przez częściowe wykonanie zobowiązania, uiszczenie odsetek lub złożenie prośby o odroczenie płatności - zob. wyrok WSA w Warszawie z 26 kwietnia 2006 r., III SA/Wa 2216/05, Lex, nr 212167; M. Faryna w: D. R. Kijowski (red.), Ustawa o postępowaniu egzekucyjnym $w$ administracji. Komentarz, Warszawa 2010, s. 802; E. Cisowska-Sakrajda, w: J. P. Tarno (red.), op. cit., s. 167.

${ }^{14}$ Według ustawy egzekucyjnej, kontroli tej nie podlegają banki, co uzasadnia się z reguły gwarancyjną rolą banków jako instytucji zaufania społecznego oraz koniecznością przestrzegania tajemnicy bankowej - zob. R. Suwaj, w: red. D. R. Kijowski, op. cit., s. 725. Na temat kontrowersji wokół tego ograniczenia uprawnień organu egzekucyjnego - zob. M. Król, Uprawnienia organu egzekucyjnego względem dtużnika zajętej wierzytelności, „Przegląd Podatkowy” 2012, nr 3, s. $30-31$. 
stracyjnego (zwłaszcza art. $7,77 \S 1$ i art. 80 k.p.a. w zw. z art. 18 upea) ${ }^{15}$. Czynności kontrolne przeprowadza upoważniona przez organ egzekucyjny osoba z urzędu z udziałem dłużnika zajętej wierzytelności jako strony postępowania kontrolnego na podstawie okazanego pisemnego upoważnienia. Kontrola kończy się sporządzeniem protokołu kontrolnego (art. 71a §5 i 6 upea), a jeśli zostaną stwierdzone okoliczności bezpodstawnego uchylania się poddłużnika od ciążących na nim obowiązków - postanowieniem o wysokości nieprzekazanej kwoty (art. 71a $\S 9$ upea) ${ }^{16}$. Przesłanka wydania tego orzeczenia jest ustalenie, że trzeciodłużnik uchyla się w sposób bezpodstawny od przekazania organowi zajętej wierzytelności albo jej części (zob. art. 91 i art. 94b upea). Należy podzielić stanowisko Naczelnego Sądu Administracyjnego, wyrażone w wyroku z 15 maja 2012 r. ${ }^{17}$, w myśl którego zawarty w art. 71a $§ 9$ oraz art. 71b upea zwrot „bezpodstawnie uchyla się” należy interpretować jako przesłankę prawna, a nie faktyczna. W konsekwencji uchylanie się przez dłużnika zajętej wierzytelności od jej przekazania organowi egzekucyjnemu z przyczyn faktycznych, przykładowo trudnej sytuacji ekonomicznej, stanowi podstawę do wydania postanowienia określającego wysokość nieprzekazanej kwoty. Postanowienie to konkretyzuje obowiązek dłużnika zajętej wierzytelności, który jest pochodną obowiązku ciążącego na zobowiązanym. Następstwem doręczenia ostatecznego postanowienia w tym przedmiocie jest wejście poddłużnika w sytuację procesową zobowiązanego ${ }^{18}$, gdyż jest ono podstawa do wystawienia przez organ egzekucyjny prowadzący postępowanie - który dokonał u dłużnika zajęcia wierzytelności - tytułu wykonawczego i wdrożenia względem poddłużnika środków egzekucyjnych, pod warunkiem wszakże nieprzekazania zajętej wierzytelności albo części wierzytelności organowi egzekucyjnemu.

Wraz z podjęciem przez organ egzekucyjny czynności zmierzajacych do zastosowania względem dłużnika zajętej wierzytelności środka egzekucyjnego, organ ten powinien doręczyć poddłużnikowi upomnienie - zgodnie z zasada ogólną zagrożenia indywidualnego egzekucją (art. 15 § 1 upea), której celem jest dążenie do dobrowolnego wykonania ustalonego obowiązku przez uświadomienie zobowiązanemu następstw jego niezrealizowania ${ }^{19}$. Należy zauważyć, że w tym wypadku doręczającym upomnienie będzie organ egzekucyjny. Rozwiązanie to jest spójne ze wspomnianą konkluzja, że postępowanie względem dłużnika zajętej wierzytelności ma charakter szczególny w stosunku do reguł

\footnotetext{
${ }^{15}$ Zob. E. Cisowska-Sakrajda w: J.P. Tarno (red.), op. cit., s. 167.

${ }^{16} \mathrm{~W}$ orzecznictwie wskazuje się, że przeprowadzenie przez organ egzekucyjny czynności kontrolnych przed wydaniem postanowienia, o którym mowa w art. 71a § 9 upea, nie jest konieczne, gdy materiał dowodowy sprawy pozwala na stwierdzenie, że doszło do bezpodstawnego uchylania się dłużnika od wpłaty zajętej wierzytelności - zob. M. Król, op. cit., s. 30 i powołane tam orzecznictwo. Ponadto według stanowiska NSA przepis art. 71a § 9 pozwala na dokonywanie kontroli innych podmiotów wymienionych w art. 71a upea - zob. wyrok NSA z 28 października 2011 r., II FSK 766/10, Lex, nr 1069956.

${ }_{17}$ II FSK 2221/10, Lex, nr 1244185.

18 Tożsamy pogląd prezentuja: P. Przybysz, op. cit., s. 195; E. Cisowska-Sakrajda, w: J. P. Tarno (red.), op. cit., s. 169-170.

${ }^{19}$ R. Hauser i A. Skoczylas, w: K. Celińska-Grzegorczyk et al., Postepowania administracyjne, sqdowo administracyjne i egzekucyjne, Warszawa 2013, s. 190-191.
} 
rządzących procedura przymusowego wykonania obowiązku skierowana do pierwotnego (,głównego") zobowiązanego oraz że organem egzekucyjnym właściwym do prowadzenia egzekucji z majątku trzeciodłużnika jest organ egzekucyjny, który dokonał zajęcia wierzytelności. Stanowisko to znajduje także uzasadnienie w wykładni ewolucyjnej. Ustawa o postępowaniu egzekucyjnym $\mathrm{w}$ administracji - w nieobowiązującym już brzmieniu - precyzowała w sposób szczegółowy, że przed wszczęciem egzekucji w stosunku do poddłużnika organ egzekucyjny powinien doręczyć zakładowi pracy upomnienie z zagrożeniem egzekucja, jeżeli zajęta część wynagrodzenia za pracę nie zostanie wpłacona $\mathrm{w}$ terminie siedmiu dni od daty doręczenia upomnienia ${ }^{20}$. Obecnie zaś zasadę tę należy wywodzić z art. $15 \S 1$ upea. Nie sprzeciwia się fakt, że egzekucja względem dłużnika zajętej wierzytelności realizowana jest w tym samym postępowaniu, co egzekucja w stosunku do pierwotnego zobowiąanego ${ }^{21}$.

W orzecznictwie sądowym na kanwie omawianej problematyki zaistniały wątpliwości co do właściwości organu upoważnionego do wydania postanowienia, o którym mowa w art. 71a $\S 9$ upea, oraz przebiegu przymusowej realizacji tego postanowienia. Rozważania w obszarze pierwszego ze wspomnianych zagadnień należy rozpoczać od wskazania, że według niektórych przedstawicieli doktryny prawa następstwem powyższego postanowienia jest zmiana dotychczasowej roli organu egzekucyjnego, który dokonał zajęcia egzekucyjnego wobec głównego zobowiązanego. W myśl tego zapatrywania w sytuacji tej organ egzekucyjny staje się wierzycielem - w rozumieniu art. 5 $\S 1$ pkt 1 upea - należności pieniężnej w wysokości ustalonej w tym postanowieniu ${ }^{22}$. Należy stwierdzić, że pogląd ten jest zbyt daleko idący. Trafnie natomiast przyjął Naczelny Sąd Administracyjny, że przepis art. 71b upea stanowi wyraźnie, że tytuł wykonawczy wystawia organ egzekucyjny, nie zaś wierzyciel - co jest zasada przy wszczęciu egzekucji. Stanowisko to sąd kasacyjny podparł słusznym spostrzeżeniem, że unormowania $\mathrm{z}$ art. $71 \mathrm{~b}$ upea maja charakter szczególny. Według NSA, wystawiając tytuł wykonawczy w trybie wskazanego przepisu, organ egzekucyjny nie działa też jako wierzyciel będący jednocześnie organem egzekucyjnym. Wystawienie w tym trybie tytułu jest działaniem organu egzekucyjnego ${ }^{23}$. Ponadto trzeba zauważyć, że sama możliwość wystawienia tytułu wykonawczego przeciwko poddłużnikowi nie oznacza, że dochodzi do wszczęcia odrębnego postępowania egzekucyjnego. W omawianym przypadku tytuł wykonawczy umożliwia organowi egzekucyjnemu ściagnięcie z majątku poddłużnika kwoty zajętej wierzytelności - do wysokości określonej w postanowieniu, lecz w dalszym ciągu na poczet egzekwowanego dotychczas obowiązku „głównego” zobowiązanego, który to obowiązek był (jest nadal) przedmiotem trwającego postępowania egzekucyjnego ${ }^{24}$. Tym

${ }^{20}$ Zob. wywody na temat ewolucji niektórych reguł dotyczących dłużnika zajętej wierzytelności - wyrok NSA z 8 października 2008 r., II FSK 928/07, CBOSA.

${ }^{21}$ Inaczej: M. Faryna, w: D. R. Kijowski (red.), op. cit., s. 802.

${ }^{22}$ E. Cisowska-Sakrajda, w: J. P. Tarno (red.), op. cit., s. 170.

${ }^{23}$ Wyrok NSA z 4 października 2012 r., II FSK 409/11, Lex, nr 1233659.

${ }^{24}$ Por. ibidem oraz m.in. wyrok NSA z 8 października 2008 r., II FSK 928/07; wyrok NSA z 30 stycznia 2013 r., II GSK 2021/11; wyrok WSA w Krakowie z 21 lutego 2013 r., I SA/Kr 2006/12 - CBOSA. 
samym nie jest właściwe przyjmowanie stanowiska, że wystawienie przez organ egzekucyjny tytułu wykonawczego względem dłużnika zajętej wierzytelności inicjuje nowe postępowanie egzekucyjne, pośrednio tylko powiązane z osobą „głównego” zobowiązanego ${ }^{25}$. Należy zwrócić uwagę choćby na fakt, że jeśli zaistnieją podstawy do umorzenia postępowania egzekucyjnego (albo jego zawieszenia) względem pierwotnego zobowiązanego, nie można kontynuować postępowania względem dłużnika zajętej wierzytelności. Jeżeli na przykład okaże się, że pierwotny zobowiązany wykonał obowiązek albo że obowiązek ten uległ przedawnieniu, oznacza to bezprzedmiotowość egzekucji wobec dłużnika zajętej wierzytelności. Także czasowe zaprzestanie prowadzenia egzekucji wobec „głównego” zobowiązanego wyklucza prowadzenie egzekucji w stosunku do poddłużnika. Zależności te rzutują na dopuszczalność stosowania środków przymusu egzekucyjnego względem dłużnika zajętej wierzytelności $\mathrm{w}$ tym samym postępowaniu, co $\mathrm{w}$ stosunku do pierwotnego zobowiąanego ${ }^{26}$. W następstwie przyjęcia takiego stanowiska nie powinno z kolei budzić wątpliwości, że organem egzekucyjnym, o którym mowa w art. 71a i art. 71b upea, jest ten sam organ, który prowadzi postępowanie egzekucyjne wobec „głównego zobowiązanego" ${ }^{27}$.

\section{INSTRUMENTY OCHRONY PRAWNOPROCESOWEJ DLUŻNIKA ZAJĘTEJ WIERZYTELNOŚCI}

Konstrukcja procedury przymusowego ściagnięcia od poddłużnika kwoty zajętej wierzytelności powinna równocześnie zapewniać mu gwarancje ochrony praw tego podmiotu wobec działań organu egzekucyjnego ${ }^{28}$. Jak stwierdziłem już powyżej, z chwilą dokonania zajęcia wierzytelności jej dłużnik staje się podmiotem postępowania egzekucyjnego ${ }^{29}$, natomiast wraz z doręczeniem mu postanowienia określającego wysokość nieprzekazanej kwoty zajętej wierzytelności zyskuje on status zobowiązanego. W związku z tym nie sposób zgodzić się z poglądem, według którego ustanowienie w art. 89 § 2 pkt 1 i art. 90 $\S 1$ upea obowiązków dłużnika zajętej wierzytelności lub prawa majątkowego oraz zagrożenie sankcjami na skutek niewywiązania się z tych obowiązków nie daje mu statusu podmiotu postępowania, a w konsekwencji - nie przysługują mu żadne uprawnienia zobowiązanego i w związku z tym nie może on wnosić środków prawnych (zaskarżenia) ${ }^{30}$. Przeciwnie, z racji wejścia poddłużnika $\mathrm{w}$ stosunek administracyjnoprawny z organem egzekucyjnym powinien on zostać objęty ochroną prawną na tym samym poziomie, co zobowiązany.

${ }_{25}$ Zob. wyrok WSA w Poznaniu z 19 maja 2011 r., I SA/Po 93/11, CBOSA; ponadto: M. Faryna, w: D. R. Kijowski (red.), op. cit., s. 794; E. Cisowska-Sakrajda, w: J. P. Tarno (red.), op. cit., s. 168.

${ }^{26}$ Wyrok NSA z 4 października 2012 r., II FSK 409/11, Lex, nr 1233659.

27 Wyrok NSA z 30 stycznia 2013 r., II GSK 2021/11, CBOSA.

28 M. Masternak, op. cit., s. 191.

${ }_{29}$ Tak samo, jak w sądowej procedurze egzekucyjnej - zob. J. Jankowski, Uczestnicy postepowania egzekucyjnego, Łódź 1992, s. 136; M. Walasik, op. cit., s. 65.

${ }^{30}$ Wyrok NSA z 10 kwietnia 2002 r., SA/Sz 2014/00, Lex, nr 83706. 
W pierwszej kolejności należy wskazać, że obowiązująca ustawa o postępowaniu egzekucyjnym w administracji nie przyznaje dłużnikowi zajętej wierzytelności żadnego środka prawnego na etapie zajęcia wierzytelności lub innego prawa majątkowego. Jak wspomniano, skuteczne doręczenie zawiadomienia o zajęciu powoduje powstanie po stronie dłużnika zajętej wierzytelności określonych obowiązków. Przepis art. $89 \S 3$ upea stanowi, że w przypadku egzekucji z innych wierzytelności pieniężnych organ egzekucyjny - jednocześnie z przesłaniem zawiadomienia o zajęciu wierzytelności pieniężnej - m.in. wzywa dłużnika zajętej wierzytelności, aby złożył oświadczenie dotyczące tego, czy uznaje zajęta wierzytelność zobowiązanego oraz czy przekaże organowi egzekucyjnemu $\mathrm{z}$ zajętej wierzytelności kwoty na pokrycie należności lub z jakiego powodu odmawia tego przekazania. W przypadku zatem gdy trzeciodłużnik twierdzi, że istnieja przeszkody prawne do przekazania zajętej wierzytelności (np. z powodu przedawnienia roszczenia ${ }^{31}$ czy wcześniejszego zajęcia wierzytelności przez inny organ egzekucyjny), przysługuje mu możliwość złożenia oświadczenia w tym przedmiocie. W przypadku odmiennej oceny tej sytuacji prawnej organ egzekucyjny uznaje, że poddłużnik w sposób bezpodstawny uchyla się od przekazania zajętej wierzytelności lub jej części i w konsekwencji wydaje postanowienie, o którym mowa w art. 71a § 9 upea. Natomiast na tym etapie postępowania egzekucyjnego dłużnik zajętej wierzytelności nie korzysta jeszcze z żadnego środka prawnego (zaskarżenia), który mógłby w rezultacie wywołać zniesienie czynności egzekucyjnych zmierzajacych do wyegzekwowania od trzeciodłużnika zajętej kwoty wierzytelności ${ }^{32}$. Takie uprawnienie przysługuje mu dopiero $\mathrm{w}$ przypadku orzeczenia $\mathrm{w}$ toku postępowania przez organ egzekucyjny o bezpodstawnym uchylaniu się przez poddłużnika od przekazania zajętej wierzytelności.

Podstawowym środkiem ochrony praw i interesów poddłużnika jest zażalenie na postanowienie określające wysokość nieprzekazanej kwoty. W jego treści poddłużnik może nie tylko kwestionować wysokość sumy wierzytelności lub innego prawa majątkowego zajętego przez organ, lecz także może wskazać na istnienie wspomnianych przeszkód prawnych, które uniemożliwiają mu realizację zajęcia. Jeśli zażalenie okaże się uzasadnione, organ egzekucyjny nie powinien podejmować czynności egzekucyjnych. W takiej sytuacji niedopuszczalne jest również obciązenie poddłużnika kosztami egzekucyjnymi, o ile takie koszty powstały. W przypadku zaś istnienia sporu co do istnienia lub wysokości wierzytelności pomiędzy pierwotnym zobowiązanym a dłużnikiem zajętej wierzytelności, który doprowadził do wniesienia przez któryś z tych podmiotów powództwa do sądu powszechnego albo przed sąd polubowny, organ egzekucyjny powinien wstrzymać postępowanie do czasu rozstrzygnięcia tego sporu.

Należy zauważyć, że konsekwencją uznania, iż dłużnik zajętej wierzytelności uzyskuje status zobowiązanego w przypadku niewykonania postanowienia organu egzekucyjnego o określeniu wysokości nieprzekazanej kwoty, jest przyjęcie, że uzyskuje on prawo do korzystania ze środków ochrony prawnej

31 Por. wyrok WSA w Gliwicach z 12 maja 2011 r., I SA/Gl 150/11, Legalis.

32 Por. podobnie: M. Faryna w: D. R. Kijowski (red.), op. cit., s. 794. 
w toku postępowania przysługującej „głównemu” zobowiązanemu ${ }^{33}$. Przede wszystkim należałoby dopuścić do złożenia przez poddłużnika, występującego w roli zobowiązanego, zarzutów w sprawie prowadzonego postępowania egzekucyjnego, po doręczeniu mu tytułu wykonawczego w trybie art. 71b upea. Zagadnienie to było również przedmiotem rozważań w orzecznictwie sądowoadministracyjnym. Tytułem przykładu w wyroku WSA w Poznaniu z 19 maja 2011 r. stwierdzono, że dłużnikowi zajętej wierzytelności przysługuje ochrona prawna w postaci wniesienia zarzutów, i taka interpretacja wspomnianych przepisów odpowiada standardom demokratycznego państwa prawnego $^{34}$. Podobne, choć nie tak jednoznaczne stanowisko wyraził NSA w wyroku z 4 października 2012 r., w którym Sąd przyjął, że po wystawieniu tytułu wykonawczego w trybie art. 71b upea można rozważać przyznanie dłużnikowi zajętej wierzytelności prawa do wniesienia zarzutów, ale tylko w zakresie obowiązku określonego w tytule wykonawczym wystawionym w oparciu o postanowienie z art. 71a $\S 9$ upea. W mojej ocenie prawo do złożenia zarzutów przysługuje poddłużnikowi wyłącznie w przypadku, gdy zarzuty te nie dotyczą tego samego przedmiotu, co złożone przez niego uprzednio zażalenie na postanowienie określające wysokość nieprzekazanej kwoty wierzytelności (art. 71b $§ 9$ zd. II upea). Przykładowo chodziłoby o sytuację, w której organ egzekucyjny wszcząłby egzekucję przeciwko trzeciodłużnikowi pomimo niewydania uprzednio wskazanego postanowienia, które w tym przypadku powinno stanowić podstawę tej egzekucji.

\section{WNIOSKI}

W konkluzji poczynionych rozważań należy stwierdzić, że sytuacje prawnoprocesową dłużnika zajętej wierzytelności cechuje największa złożoność spośród wszystkich uczestników postępowania egzekucyjnego w administracji względem obowiązków pieniężnych. Należy zauważyć, że pierwotną przyczyna takiej wyjątkowości sytuacji poddłużnika jest niewątpliwie to, że wchodzi on w stosunek administracyjnoprawny z organem egzekucyjnym niejako „wtórnie”, biorac pod uwage fakt, że postępowanie egzekucyjne zostaje wszczęte wobec niewykonania obowiązku przez „głównego” zobowiązanego. Złożoność sytuacji procesowej trzeciodłużnika wynika także z różnorodności stosunków prawnych, w jakich pozostaje ten podmiot w toku tego postępowania, a ponadto ze specyfiki obowiązków procesowych, jakie na nim ciążą, oraz ze szczególnego rodzaju instrumentów prawnych, jakie przysługują organowi egzekucyjnemu w celu przymuszenia poddłużnika do wykonania tych obowiązków.

Powyższa złożoność sytuacji trzeciodłużnika przejawia się w tym, że w toku administracyjnego postępowania egzekucyjnego może on zajmować status zarówno osoby trzeciej, jak i uczestnika postępowania egzekucyjnego, a także

${ }^{33}$ Pogląd taki prezentują: M. Faryna, w: D. R. Kijowski (red.), op. cit., s. 794, oraz E. Cisowska-Sakrajda, w: J. P. Tarno (red.), op. cit., s. 168.

${ }^{34}$ I SA/Po 93/11. 
zobowiązanego. Zmiana pozycji procesowej dłużnika zajętej wierzytelności dokonuje się w tym samym postępowaniu egzekucyjnym, co względem pierwotnego zobowiązanego. W odróżnieniu od sądowego postępowania egzekucyjnego, gospodarzem postępowania egzekucyjnego w administracji pozostaje cały czas administracyjny organ egzekucyjny.

dr Przemystaw Ostojski

Wojewódzki Sad Administracyjny w Poznaniu

p.ostojski@wsa.poznan.pl

\section{DEBTOR OF A SEIZED DEBT IN ADMINISTRATIVE ENFORCEMENT PROCEEDINGS}

\section{Sum mary}

The article focuses on the legal situation of a debtor of a seized debt in administrative enforcement proceedings, his procedural obligations relating to the enforced seizure of the debt, the execution aimed at the under-debtor as well as the rights of the debtor in the course of the enforcement proceedings. The aim of the study is to present the complexity of the procedural situation of the debtor of a seized debt in administrative enforcement proceedings.

It is concluded that the debtor of a seized debt may act in administrative enforcement proceedings in three, separate roles: as a third party, as a participant in the enforcement proceedings, or as the obliged party. The change of the legal situation of the under-debtor is taking place in the very same enforcement proceedings as these related to the person originally obliged. 
Copyright of Journal of Law, Economics and Sociology is the property of Faculty of Law and Administration of Adam Mickiewicz University in Poznan and its content may not be copied or emailed to multiple sites or posted to a listserv without the copyright holder's express written permission. However, users may print, download, or email articles for individual use.

Właścicielem praw autorskich do „Ruchu Prawniczego, Ekonomicznego i Socjologicznego” jest Wydział Prawa i Administracji Uniwersytetu im. Adama Mickiewicza w Poznaniu. Zawartość czasopisma nie może być kopiowana, przesyłana do innych stron internetowych bądź zamieszczana na blogach bez pisemnej zgody wydawcy. Niemniej artykuły można drukować, kopiować lub przesyłać w formie elektronicznej na własny użytek. 